\title{
Social Order and Art Sources of Imaginations*
}

\author{
Alexander F. Filippov \\ Doctor of Sociological Sciences, Professor, Head of the Centre for Fundamental Sociology, \\ National Research University-Higher School of Economics \\ Address: Myasnitskaya str., 20, Moscow, Russian Federation 101000 \\ E-mail: filippovaf@gmail.com \\ Nail Farkhatdinov \\ $\mathrm{PhD}$, Senior Research Fellow, Centre for Fundamental Sociology, \\ National Research University-Higher School of Economics \\ Address: Myasnitskaya str., 20, Moscow, 101000, Russian Federation \\ E-mail: nfarkhatdinov@hse.ru
}

In a novel published in the middle of the 1960s, the famous Soviet science fiction writers, the brothers Arkady and Boris Strugatski described an experiment; the character of the novel travelled into a depicted future, or, better yet, a series of futures ordered according to the time of the appearance of the corresponding works of fantasy. With a timemachine of the imagination, he started with the first antique dialogues on the ideal state, and continued through the technological utopias of the recent past. Finally, he landed in the rather dark fantasies of mankind divided by an iron wall into hostile worlds, attacked by savage robots, and colonized by extra-terrestrial creatures. All of these images were familiar to the fans of the sci-fi literature of that time. With bitter sarcasm, the Strugatski brothers mentioned the "half-translucent" (i.e., poorly and unconvincingly depicted) inventors of clever machines, parodied the unnatural talk of the "people of the future", and mocked stereotyped stories. Back in his "real" world, the narrator (by the way, he is a software developer in the research institute "of sorcery and magic") ${ }^{1}$ finds his colleagues vividly discussing inter alia the quasi-scientific ideas formulated in the observed fictions. Whereas they find what he saw during his journey interesting, he has a small talk with one of his colleagues: "When I finished my story he asked, 'Didn't this Sedlovoi [the experimentator] try traveling in the described present? In my opinion that would have been much more amusing ..."' (Strugatski, Strugatski, 1977: 113).

Well, to put it bluntly, the idea of this special issue was this: try traveling in the described present, or, better, in the many presents re-presented through works of art and literature. The multiple worlds visited can be full of strange talks and characters that would hardly be met in real life. They would not only be the worlds of the present in

* The results of the project "Between Political Theology and Cognitive Sciences: New Alternatives, New Challenges, or New Resources for Social Theory" carried out within the framework of the Basic Research Program at the National Research University Higher School of Economics (HSE) in 2020, are presented in this work.

1. "Thaumaturgy and Spellcraft" in the cited translation. 
the narrower sense, but also reach into the deep past or, alas, into the imagined future again. However, they would belong to our time in the broader sense, contain ideas worth discussing, report facts, and contain narratives of significant value for sociology. They all would be worth analyzing as attempts at the comprehension of reality, and they are, in themselves, an important part of this reality.

This may seem to be the most painful moment and the point of vulnerability of our position. Is it not an outdated understanding of literature and art a kind of mirror to reflect reality? Does it not look as if we have re-imagined and inverted the situation of classical sociology competing with the literature in a rather naïve vein? In fact, thanks to the brilliant research of Wolf Lepenies, we know this paradigmatic situation of sociology just by its start as a discipline: "As soon as sociology had advanced its claim to be a self-sufficient discipline it saw itself confronted not only by the ill will of the established disciplines but also by competition on the part of literature ... some branches of literature claimed a status equal to many scientific disciplines so far as the advancement of knowledge was concerned" (1992: 6). For Lepenies, sociology oscillated between science and literature: it tried to imitate the natural sciences but failed to become "a true natural science of society"; it abandoned its scientific orientation and moved "perilously close to literature" (Ibid.: 7). More than a century after this paradigmatic situation came to the fore, Robert Nisbet could keep comparing sociology and art as mutually complementary: "I have also been struck repeatedly by the number of instances in which visions, insights, and principles native to sociology in its classical period were anticipated, were set forth in almost identical shape and intensity, by artists, chiefly Romantic, in the nineteenth century". He counted such names as "Burke, Blake, Carlyle, Balzac, and a score of others whose reactions to the democratic and industrial revolutions created a pattern of consciousness that the sociologists, and others in philosophy and the sciences, fell into later" (Nisbet, 1976: 8). Even today in a perhaps more modest and critical way, a certain consensus concerning sociology and fiction would be stated, for example, in using nonsociological resources for teaching sociology: "This consensus is evident in the collection of readings of fiction for sociological purposes and the growing corpus of articles highlighting the usefulness of individual works of fiction. That is, there is a consensus that non-sociological resources are useful and a consensus that particular non-sociological resources are useful for teaching particular aspects of sociology" (Carlin, 2010: 212). The word consensus can be misleading. Today's use of non-sociological sources is far from the situation of the competition between literature and social science of the 19th century. What we need is clarity of the change of the attitudes of modern science against both art and its ambitions of the past. To demonstrate this, we simply compare the arguments of Howard Becker, one of those who belongs to the tradition of social ethnography with a very sensitive attitude towards the writing and literary features of research texts. One of his arguments is outlined in his book Telling about Society, in which he lists different types of narration. Novels, dramas, films, and photography are placed in a list with geographical maps, statistics, etc. (2007: 8ff.). Literature and art can be informative and instructive: this is true, this is a common place, and we have stated a consensus about this. 
However, in his classic earlier book, Becker (1982: xxiv) said something very substantial, and even though he himself called it common place by only considering the conclusions from it not being obvious, we will quote his words at some length:

I think it generally true that sociology does not discover what no one ever knew before, in this differing from the natural sciences. Rather, good social science produces a deeper understanding of things that many people are already pretty much aware of. This is not the place to pursue that argument. But I should say that whatever virtue this analysis has does not come from the discovery of any hitherto unknown facts or relations. Instead, it comes from exploring systematically the implications of the art world concept.

Becker's 1982 work, Art Worlds, is not a theoretical work: it is an attempt to present a simple analytical framework for the sociological analysis of what is considered to be art in society. This analysis does not restrain itself to specific domains of reality, but instead it can be read as an invitation to look beyond what the sociology of art traditionally focuses on. Although, for Becker, the worlds of art are networks of people, not provinces of meaning: we can use the concept in both senses to reformulate our position.

We want to keep a distance from the conception of art-as-reflection that was basic for several generations. Seeing social science and literature as mirrors leads to the endless discussion which is better in terms of reflecting 'real life. This was the subject of the outdated competition! Today, we can hardly share any version of reflection theory as described by Milton Albrecht, for example, in his influential paper from more than half a century ago: "The historical emphasis on reflection has naturally tended to distract attention from the question of the influence of literature on society, but the two concepts have frequently been regarded as mutually influential or as opposite sides of the same coin" (1954: 431).

We are too far from those times: neither does sociology finds itself in competition with literature, nor does literature compete with a new ambitious science, imitating, on their own, the hard sciences. In literature, we can find characters called sociologists; in sociology, we know few branches that can be identified as the sociology of literature (or literature and arts). Both, sociology and literature, observe each other not without interest but with rather-distracted, unfocused attention: both make use of each other as sources, although not as sources of certain, reliable information, but rather as sources for social imagination and the reconfiguration of knowledge. In fact, this is the problem of an observer: if someone compares sociology and literature as two mirrors of the same society, the mirror can be a looking glass, but it can be a burning glass as well. Literature (and sociology) can reflect, and it can influence people, inspire them, and inform their actions and behavior. But, who compares these two mirroring domains? Who is the observer holding both mirrors or both sets of mirrors? Who is enabled to compare not only reflections or effects on society, but also the reliability of those reflections and intentions of those who try to influence society? Well, we know the answer: it is no one or everyone. There is no position of privilege in society: there is no chance to find any means to 
discriminate between the different forms of knowledge according to their adequacy or effectiveness. This is why sociology does not come closer to understanding reality, even if it tries to use more and diverse resources including arts and literature. It comes closer to its own task, which is to produce other arguments and forms of the self-description of society through the temporary distancing from itself, i.e., from its own ways of reproducing knowledge. If sociologists stay in their professional 'province of meaning', they will hardly be able to reach the reality as seen without their professional optics. If they are not so alien to their tradition, or the way of serious comprehension and analysis of the world of arts and works of art, sociologists will enrich their own science and their capacities to reconfigure knowledge that society needs to better understand itself.

In the call for papers, we argued that we would like to frame our endeavor as cultural-sociological, focusing mainly on how culture and arts, being autonomous, shape social action. Interestingly, anthropology has become an important foundation for cultural sociology. While sociological thought after 1945 was more concerned with how the discipline of the sociology of culture and arts should be established in contrast with aesthetics and art/literature theory, anthropology has been open to collaborations with nonsociological disciplines and aesthetic practices. The aesthetic realms have always been a way to understand social life from an anthropological perspective. In particular, one can mention the works of Clifford Geertz and Victor Turner, both having approached arts, poetry, and theatre from the anthropological perspective in order to produce coherent sociological knowledge. Geertz's essay "Art as Cultural System" (1976) seems to be the most relevant for the research perspective proposed in this special issue. The CfP contains the following passage:

In "Art as a Cultural System" (1976), he [Geertz] wrote that "to study an art form is to explore a sensibility" and "such a sensibility is essentially a collective formation, and that the foundations of such a formation are as wide as social existence and as deep". Furthermore, he argued that the relation between art and society should be treated as ideational, not mechanical, meaning that art is a primary document (not a mere representation) since it does not illustrate the dominant ideas (the ideas of dominant class, as Bourdieu would put it). Instead, artworks are conceptions along with other conceptions (including philosophical, sociological, and political).

Arguing that artwork, literature, music, and other forms are conceptions, we suggest that the analysis of particular examples would be at least comparable to the analysis of other forms of social, political, expert, and mundane forms of the knowledge of society, social order, and social action. In a similar way, scholars such as Robert Witkin and Tia DeNora used the cases from the historical sociology of arts. Witkin provided the analysis of Manet's Olympia, following how the constraints and dichotomies of bourgeois society (discourses of values vs. discourses of motives, female home vs. male market, etc.) were enacted via the iconic painting. He wrote that "Olympia takes its place as one among a number of cultural resources that serve to unmask the pretense and illusion involved in the politics of desire and in the spiritual claims of a sphere of purely personal relations in 
modern society" (1995). Tia DeNora studies music, and in her case, explores the musical culture of Vienna of the early 18th century. Her materials include philosophical, musicological, and practical knowledge as resources for the new models of social agency to emerge, and in particular, the form of agency that extrudes females from the practice of piano performances. What we received from the authors of this issue may be seen as a series of contributions to this fruitful tradition.

The RSR special issue includes eight contributions. They vary in topic and the research focus. In what follows, we provide a brief overview of the contributions that are included in the issue.

There is a group of papers that deal with literature as empirical material. Jana Váña's contribution opens the issue, and sketches out a cultural sociological theory of literature. He focuses on the interactions between literature and sociological knowledge, and begins with the discussion of examples of sociological and anthropological studies to reveal their aesthetic grounds. At the same time, literature can be viewed as a sociological resource. Here, Váňa identifies two sociological phenomena often addressed via literature, those of the existential experience (often dismissed in sociological writing) and Zeitgeist. The paper concludes with the outline of the next conceptual steps towards the meaningfullyoriented sociology of literature.

The second paper on literature is Werner Binder's study of the popular science-fiction book series Culture, by Ian Banks. Being a literature construction, Culture is a liberal utopia and realm where Banks considered various contradictions of the liberal myth. Binder's analysis proceeds from the cultural sociological theory of civil society as outlined by Jeffrey Alexander. Following his theory, Binder argues that science-fiction literature contains a specific liberal myth that underlies the narrative, referring not only to the fictional realm of specific writing, but also to the existing liberal order.

Vladimir Kamnev's and Vladimir Bystrov's research paper is an example of how to create sociological theory with science fiction. Approaching science-fiction, they revisit one of the fundamental problems of sociological theory-the problem of the Other. They begin with establishing connections between the examples of science-fiction literature and social philosophical concepts (e.g., Ivan Efremov is put together with Edmund Husserl, while Max Weber's ideas can be found in Sergey Snegov's and Clifford Simak's oeuvre). Generally speaking, Kamnev and Bystrov identify two ways sci-fi literature constructs the Other. One way is based on the rational possibility of establishing relations with the Other, while the second way proceeds from the irrational foundations of the Other, and therefore, on the impossibility of getting in touch with the Other. The conceptual distinction applied by Kamnev and Bystrov in the analysis of Ray Bradbury's The Martian Chronicles reveals a postcolonial meaning of science-fiction literature.

The next paper approaches the song-poetry of the Soviet estrada and its cultural meanings. Anna Ganzha provides a cultural sociological program of song studies in which she combines Adornian analyses with a recent, meaningfully-oriented perspective. Her main concern is to put mass song back into the realm of culture, i.e., the relationship of cultural policy with the song form itself. Using a number of examples from the history of Soviet 
mass song, Ganzha explores how the form was a "public presentation of social topos". According to Ganzha, Soviet songs did not merely transfer ideological messages since their role was significantly broader than to sing out the social world.

Andrey Adelfinsky's contribution focuses on Soviet cinema to study how movies represented the transformation of sports in the USSR. He systematically classifies primarily the movies of the 1950s-1980s into three groups. The first group of movies constructs the sportsman as a hero, while the second group of movies puts sport practice in the realm of irony and comedy. The third group of movies represents the transformation of sport institutions as close as is possible to what actually happened. Adelfinsky shows the changes of the function that movies had. After ceasing to be a propaganda tool to promote a healthy lifestyle among all Soviet citizens, cinema turned to the promotion of elitist and professional sport as a performance. Yet, these representations had nothing in common with what changed in sports institutionally. In this respect, sport movies were (and maybe still are) establishing an autonomous realm.

The next two papers look at the history and interactions of cultural and social thought. Maria Chernovskaya's essay traces the reception of Walter Benjamin's ideas in the USA with the help of the theory of cultural transfer as proposed by Michelle Espagne. Walter Benjamin's intellectual legacy has become a foundation for many contemporary disciplines and artistic practices. He himself may be considered as the one who analyzed aesthetic phenomena, and through his analysis, grasped the tendencies of modern life. In this particular paper, Chernovskaya argues that Benjamin's image in the USA was far broader than that of a left-wing cultural theoretician, and thus his writings had a deeper impact on the research configuration and interests of American cultural scholars in the aesthetics of everyday life.

In his paper, Boris Stepanov reviews the interdisciplinary field of cinematic sociology and revisits the relations with cognate disciplines such as film and cultural studies. Stepanov questions the marginal place of cinema as a resource for the study of social imagination, and attempts to provide a coherent explanation of the state of art. He argues that cinema may occupy a more significant position among the aesthetic objects in sociology once the relation between the disciplines is mediated through an anthropological turn in contemporary culture studies.

The issue closes with the book review. The book under consideration is titled Roads to Music Sociology (2019), and celebrates the 5oth anniversary of the Department of Music Sociology at the University of Music and Performing Arts in Vienna. In the review, Nail Farkhatdinov discusses the theoretical agenda of contemporary music sociology and considers the empirical promises of the discipline.

With the publication of the special issue, it is now clear that the initial idea of the special issue was probably too narrow since the contributions, strictly speaking, fail to stay within the methodological limits imposed by the editors. Yet, this confirms that the task of using artworks as sources of imagination and of doing what Geertz called the "ethnography of the vehicles of meaning" requires multiple perspectives. 


\title{
References
}

Albrecht M. C. (1954) The Relationship of Literature and Society. American Journal of Sociology, vol. 59, no 5, pp. 425-436.

Becker H. S. (2007) Telling about Society, Chicago: University of Chicago Press.

Becker H. S. (1982) Art Worlds, Berkeley: University of California Press.

Carlin A. P. (2010) The Corpus Status of Literature in Teaching Sociology: Novels as "Sociological Reconstruction". American Sociologist, vol. 41, no 3, pp. 211-231.

Denora T. (2006) Music as Agency in Beethoven's Vienna. Myth, Meaning and Performance: Toward a New Cultural Sociology of the Arts (eds. R. Eyerman, L. McCormick), Boulder: Paradigm, pp. 103-120.

Geertz C. (1976) Art as a Cultural System. Modern Language Notes, vol. 91, no 6, pp. 14731499.

Lepenies W. (1992/1988) Between Literature and Science: The Rise of Sociology, Cambridge: Cambridge University Press.

Nisbet R. (1976) Sociology as an Art Form, Oxford: Oxford University Press.

Strugatsky A., Strugatsky B. (1977) Monday Begins on Saturday, New York: Daw Books.

Witkin R. W. (1997) Constructing a Sociology for an Icon of Aesthetic Modernity: Olympia Revisited. Sociological Theory, vol. 15, no 2, pp. 101-125.

\section{Искусство как ресурс социологического воображения}

\author{
Александр Филиппов \\ Доктор социологических наук, профессор, руководитель Центра фундаментальной социологии, \\ Национальный исследовательский университет «Высшая школа экономики» \\ Адрес: ул. Мясницкая, д. 20, г. Москва, Российская Федерация 101000 \\ E-mail: filippovaf@gmail.com
}

Наиль Фархатдинов

$\mathrm{PhD}$, старший научный сотрудник, Центр фундаментальной социологии, Национальный исследовательский университет «Высшая школа экономики»

Адрес: ул. Мясницкая, д. 20, г. Москва, Российская Федерация 101000

E-mail: nfarkhatdinov@hse.ru 